\title{
Historein
}

Vol 14, No 1 (2014)

On the Edge of History and Philosophy

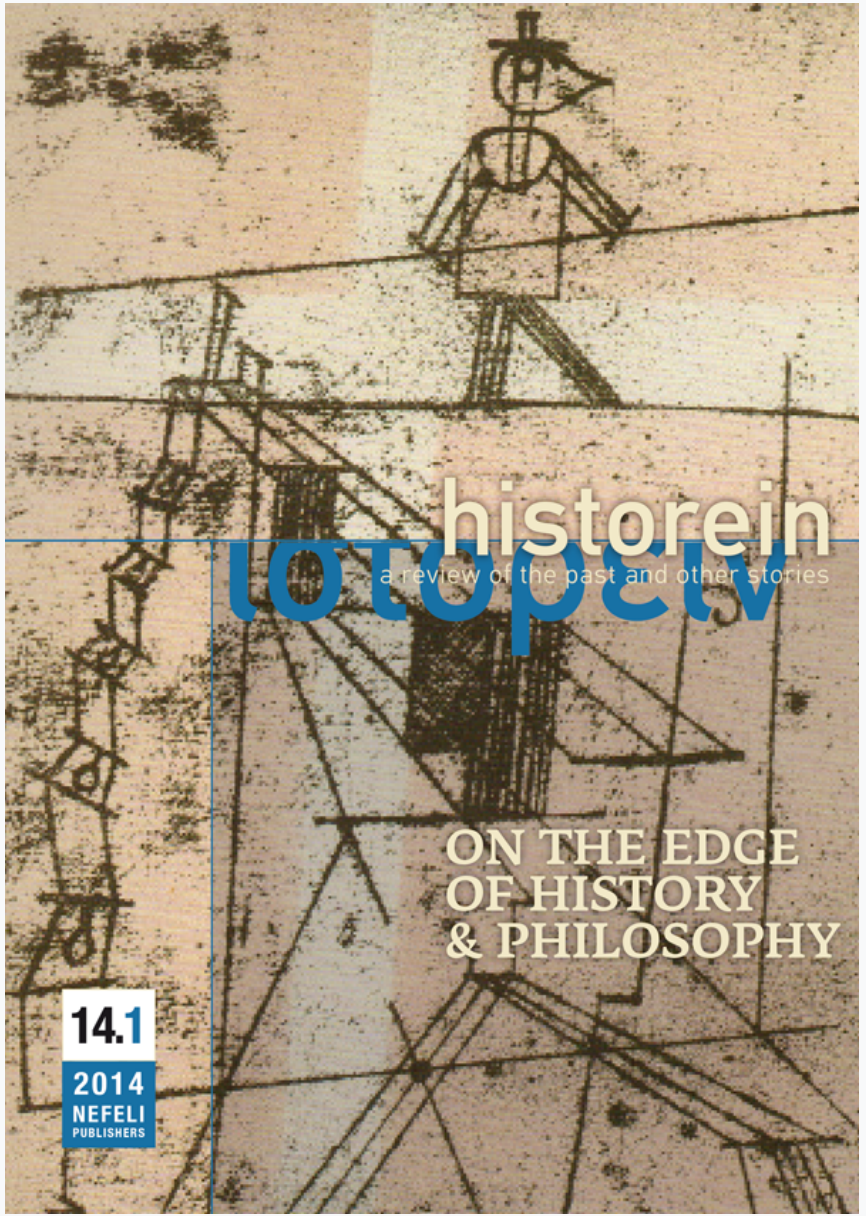

\section{Explorations between philosophy and history}

Chris F.G. Lorenz

doi: $10.12681 /$ historein.217

Copyright $\odot$ 2014, Chris F.G. Lorenz

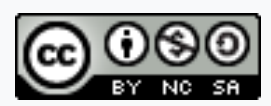

This work is licensed under a Creative Commons Attribution-NonCommercialShareAlike 4.0.

\section{To cite this article:}

Lorenz, C. F. (2013). Explorations between philosophy and history. Historein, 14(1), 59-70. https://doi.org/10.12681/historein.217 


\section{DIALOGOS}

My 2009 book Przekraczanie granic: eseje z filozofii historii i teorii historiografii [Bordercrossings: essays on the philosophy of history and theory of historiography] ${ }^{1}$ is entitled thus because its chapters are located in the borderlands between history and philosophy. They are based on my research in philosophy of history and historiography over the past 20 years. Although they have been produced in a numerous contexts and have been published in a variety journals and collected volumes, there is some underlying coherence which connects them and which I shall address in this introduction. At the same time, the selected articles represent articulations of my own position in theoretical and historiographical debates.

\section{Three basic ideas: 'cross-}

\section{disciplinarity', 'conceptual inversion' and 'essentially contested concepts'}

The first basic idea which connects the articles is that the writing of history has a "border crossing" character, meaning that history writing involves bordercrossings, first, between history and philosophy and second, between history and "politics" in a broad sense. History is often characterised as "a discipline of context" and historiography can, in my view, only be understood by contextualising it, both in cross-disciplinary and in political ways. Although this may sound pretty "postmodern" to some, my arguments in case are usually directed against and opposed to "postmodernist" positions. The second basic idea connecting the articles is the idea that the mechanism of "inversion" (or "negation") is important for our understanding of debates in philosophy of history and in historiography. I would even suggest that this holds for intellectual history in general. The "dialectical" mechanism is

\section{Explorations}

\section{between philosophy \\ and history}

\section{Chris Lorenz}

Ruhr University Bochum

VU University Amsterdam

Duitsland Instituut Amsterdam 
explanatory in many intellectual debates because positions often owe their origin and existence to an inversion of the position that constitutes the object of critique. Classical examples of this procedure in history are found, for instance, in Marx's materialistic inversion of Hegel's idealism, in Fernand Braudel's "structural" inversion of the political history of events ("'histoire evénementielle") or in the inversion of Braudellian structural "macrohistory" into "microhistory" by Carlo Ginzburg and Gianni Levi. ${ }^{2}$ As a consequence, the "inverted" positions retain the same conceptual structure as the criticised ones, carrying along similar conceptual problems (same contrasts, dichotomies etc).

Controversies about history are my favourite point of departure, because in controversies much of what is usually left implicit and is taken for granted by historians is questioned. Contrary to what many historians hold, I think that controversies are generally productive and good - both for history and for philosophy of history. This is the third basic idea behind this volume. I thus subscribe to Bacon's argument in favour of the experimental way to the knowledge of nature. His argument in favour of experiments was that "in order to find out the true character of a lion, you have to pull its tail". Similarly I think that it is best to study historians when they are pulling each other's tails. So I agree with Paul Feyerabend's point of view that "prejudices are found by contrast, not by analysis". ${ }^{3}$ Finding controversies concerning the past is not so difficult because all key concepts in the humanities are "essentially contested concepts", as WB Gallie has coined their "discursive condition". ${ }^{4}$

I have organised the texts in two clusters: "philosophy" and "historiography". This division is not accidental, because the kind of philosophy of history I am advocating is based on history writing or historiography in general, and on controversies about history and in history writing in particular. ${ }^{5}$ | subscribe to a style of philosophising that Raymond Martin has labelled the "empirical philosophy of history" - empirical because it is based on concrete controversies about the past. ${ }^{6}$ In the philosophy of science and in "science studies" too, this empirical style has, in my view, produced the most interesting (case) studies since Thomas Kuhn revolutionised this field in the 1970s.

\section{Philosophy of history: the 'historical past' and 'practical past'}

However, philosophy of history, in my view, cannot be restricted to a conceptual analysis of the problems of historical controversies, because history is not only about the "historical past", but also about the "practical past", as philosophers of history as different as Hayden White and Jörn Rüsen have emphasised during their long careers. ${ }^{7}$ Therefore, philosophy of history cannot be restricted to epistemology, logic and methodology; it also has to address the ethical, political and metaphysical or ontological aspects of history. History should not only be analysed from the epistemological perspective of a - distant - observer, but also from the ethical and political perspective of the - involved - participant, that is from the perspective of political actors. And here I am not talking about the political actors in the past, who are an object of historical research and writing, but about the historians themselves as political actors in the present. Professional, academic history always has had a strong inclination to turn a blind eye to its own inevitable political involvement. Given its political record, and especially its entanglement with the nation-state, this "blind spot" regarding "the politics of history" is quite remarkable and appears like a kind of collective, "professional repression". In recent decades, one only needs to look at the many forms of "commissioned history" to 
conclude that the idea of "apolitical" history is not only misconceived, but also a "covering up" in a literal sense - and thus ideological. All history writing, in my view, is "commissioned" in a broader sense, as both Barkan and Hölscher have also recently emphasised. ${ }^{8}$

Therefore, in my analyses of historiography, I have not only addressed epistemological and methodological questions, but also the political and ethical questions involved in our dealings with the past. For a long time, these questions have been discussed under the label of "the problem of partisanship" or "the problem of values", but since Foucault and postcolonial studies they are usually framed in terms of "power/knowledge" and of "discourse". Therefore, dealing with both the epistemic/methodological and the practical aspects of history - and analysing their interconnections - usually are at the centre of my approach. Therefore, dealing with the past - whether the past is chronologically "distant" or not - in my view is always also a form of "doing history", or of "making history" in the present, to be more precise.

In both the philosophical and in the historiographical part of my work, I have used the concept of "historical identity" in order to analyse the reflexive aspects of "doing history" - reflection literally meaning "to turn back to oneself". My interest in the interconnections and intersections of the epistemological and the practical aspects of history - my double epistemological-practical focus, so to speak - distinguishes my approach from both classical analytical philosophy of history and from modern narrative philosophy of history. If you are looking for a label, you could call my approach "post-foundational"; although this label is pretty broad, in the past I also have used Hilary Putnam's concept of "internal realism" in order to label my position

Within post-foundationalism, the very distinction between facts and values becomes relative - for the same reason why the distinction between facts and theories has become relative. This is so because the presupposed "gap" between them - based on the idea that factual statements have a foundation in experience and normative statements lack this foundation - can no longer be upheld. This, of course, does not mean that both types of statement are the same - although both are "foundationless" - but it does mean that the distinction between facts and values is relative and can better be analysed than postulated.?

Therefore, "internal realism" is not "power blind", as some have suggested. ${ }^{10}$ To the contrary, "internal realism" opens up the terrain of "the politics of method" for rational inquiry and debate. So, although I have criticised specific arguments of Foucault's and of postcolonial theory concerning the ("totalising") relationship between power and knowledge, I certainly do not reject their type of analyses in toto. I find some of Foucault's ideas - for instance about "Othering" - of fundamental importance to the humanities. "And in my recent publications, I also have argued that Dipesh Chakrabarty's (postcolonial) concept of the "historical wound" is important to help us understand the experience of "historical injustices" in the "post-Holocaust condition". ${ }^{2}$ Simultaneously, however, I agree with Frederick Cooper's critique that Chakrabarty is "homogenising" "the West". So, in my view, it is not strange or inconsistent that one criticises authors from whom one also "lends" ideas. This is also the way in which I would describe my intellectual relationship with the two philosophical fathers of narrativism in philosophy of history, Hayden White and Frank Ankersmit (see below). 


\section{Against relativism and objectivism, including their 'inverted' forms in narrativism}

My "double focus" explains the double line of argument which readers can find in many of the contributions to this volume: first, arguments against relativism, in its classical and postmodern varieties, and, second, arguments against objectivism, in its classical empiricist and its positivistic varieties. ${ }^{13}$ Basically, what I am arguing is that both objectivism and relativism are philosophical legacies of empiricism and of positivism.

Let me first explain why I still regard objectivism - both in the form of empiricism (as an epistemological position) and of positivism (as a methodological position) - as a major problem in philosophy of history, because some could be tempted to regard this kind of criticism to be as meaningful as flogging a dead horse. Well, the horse of "objectivism" is not quite as dead as it should be, in my view, because it lives on in various guises. This leads me to the problem of conceptual inversion in philosophy of history.

In the first part of my book, I argue that although empiricism and positivism have been declared "dead" in philosophy of science since the 1970s at the latest, they still are very much alive in philosophy of history in inverted forms. "Post-foundationalism" has not completely arrived in philosophy of history, so to speak, as also Avi Tucker, Mark Bevir and John Zammito have recently been arguing. ${ }^{14} \mathrm{My}$ argument for this thesis is the observation that quite a few problems that are still dealt with by philosophers of history continue to presuppose the validity of some fundamental ideas of empiricism and of positivism.

Let me illustrate what I mean with one example - from a philosopher of history whose positions I have fundamentally criticised over a longer period of time and whose books have been translated in many languages, including Chinese: Frank Ankersmit. Let me first state my great respect for this most systematic thinker of present-day philosophy of history. From his dissertation Narrative Logic (1983), to his books Historical Representation (2002), Sublime Historical Experience (2007) and Meaning, Truth and Reference in Historical Representation (2012), he has defended the same line of argument with remarkable consistency. This is the argument that, for a philosophical understanding of history writing, the distinction between two kinds of linguistic entities is absolutely fundamental. This is the distinction between singular descriptive, referential statements - like "Joseph Stalin died on 5 March 1953 in Moscow" and "Japan surrendered to the Allies on 2 September 1945 on the USS Missouri" - which presuppose no theories and whose truth-value can be decided independently of other statements on the one had, and, on the other, non-descriptive, nonreferential complex linguistic entities, devoid of any truth-value. His standard examples of these complex linguistic entities are notions like "feudalism", the "Enlightenment" or the "Baroque". Ankersmit baptised these complex linguistic entities in the 1980s as "narrative substances" and later on - from the 1990s - he has relabelled them as "historical representations". Characteristic of these linguistic entities, according to Ankersmit - and he has never tired of emphasising this over and over again - is that they are devoid of any cognitive content of their own. Narrative substances and historical representations just generate points of view - or perspectives - from which we can look at the past, but they are not to be found in the past, nor do they refer to anything in the past. 
In short, narrative substances and historical representations cannot be "fixed" to anything in the past. Therefore, according to Ankersmit, they only exist in a linguistic universe and are devoid of any truth-value. Much of what Ankersmit has written are inquiries into the logical nature of these cognitively "empty" complex linguistic entities, which in his view (following Arthur Danto's view on objects of art) function like substitutes of past reality. Given the unbroken continuity of his line of argument, it is not accidental that in an interview he has called his dissertation, Narrative Logic (1983), his "best book". Indeed it is, because it formulated the "agenda" for the rest of his books since. ${ }^{15}$

Now, what I find problematic in Ankersmit's central line of argument is that the very opposition between a descriptive statement and a perspective - and therefore the opposition between individual descriptive statements in narratives and the complex "narrative substance" they collectively generate - is taken over from empiricism without questioning. ${ }^{16}$ At stake is the idea that there is a fundamental opposition, on the one hand, between proper names and individual descriptive statements - formerly known as Protokollsätze - which individually and directly refer to reality and whose reference can be "fixed", and, on the other, that there are sets of non-descriptive statements - in science usually known as "theories" and in history as "narratives" (or "narrative substances" and "representations"), whose reference to reality cannot be "fixed". As is well known, empiricists have tried long and hard to construct the "fixes" between the theories and the observation statements in (philosophy of) physics in the hope of "reducing" theories to observational statements. This was the programme of logical-positivism from the 1930s onwards. And, as we all know only too well, this project turned into one of the most interesting failures in the history of philosophy of science in the 1960s and 1970s. However, in conformity with this opposition deriving from empiricism, Ankersmit is still arguing that singular, descriptive statements can be individually "fixed" to reality, while "narrative substances" and "historical representations" cannot be "fixed" to reality. ${ }^{17}$ They can only be compared to each other - and Ankersmit at some points in time has proposed to express their relative qualities in terms of "relative objectivity".

However this may be, Ankersmit's fundamental argument is still based on the empiricist idea that individual descriptive statements do not contain any perspectival element and that they can be "fixed" - and thus somehow "founded" - in observation. ${ }^{18}$ It is also based on the empiricist idea that without this referential "fixity", statements have no cognitive content. The very idea of "fixing" individual descriptive statements to (the experience of) reality, however, has been discredited effectively and definitively by post-empiricism and post-positivism - from Quine to Popper and Kuhn and beyond. This idea has been replaced by the insight in "the theory-ladenness of all empirical observation" and thus by the insight that all individual knowledge-claims are embedded in a "web of beliefs" and therefore have a "network-character". This insight - dubbed "semantic holism" by Quine - remarkably - was not incorporated in Ankersmit's original philosophy of history in 1983, and it was explicitly rejected by him in his latest book, in $2012 .{ }^{19}$

This legacy of empiricism in Ankersmit is all the more remarkable since he has been dealing with both Quine and Popper directly. Nevertheless, he has been rejecting the very idea of the "theoryladenness" of descriptive statements in history explicitly, from Narrative Logic to Meaning, Truth and Reference. And he does so for good philosophical, that is for systematic, reasons. He does so, I must assume, because all of his fundamental conceptual distinctions - between description and 
representation, and between the "fixability" of singular descriptive statements and the "non-fixability" of narrative substances and representations - and as a consequence their respective Wahrheitsfähigkeit and Wahrheistunfähigkeit depend on it.. ${ }^{20}$ This is one important example of the continuing presence of "objectivism" - that is both empiricism and positivism - in inverted forms in philosophy of history.

Another important example of "inverted empiricism" can be found in some of the work of the other "grand old man" in present-day philosophy of history, Hayden White. As with Ankersmit, my admiration for many of White's achievements goes hand in hand with fundamental criticism. What I have been criticising is what looks like an expulsion of epistemological questions and questions of explanatory logic from philosophy of history in White's Metahistory. This "expulsion" is the consequence of limiting philosophy of history to philosophy of historical writing. By arguing that the preferences of historians for modes of emplotment, and so on, are conditioned only by aesthetic and ideological reasons and are unconnected to issues of epistemology, White in Metahistory did just that, just like Ankersmit was doing by arguing that narrative substances are "autonomous" from historical research and empty of any cognitive content. Therefore, I was basically arguing for a balanced approach to philosophy of history, including both the new questions that White and Ankersmit had put on the agenda concerning historical writing, and the old questions of epistemology and methodology concerning historical research. Again I was arguing against an eitheror approach, and this time against the reduction of philosophy of history to philosophy of history writing because this reduction amounts to an "inversion" of its former reduction to the philosophy of historical research by analytical philosophy. With authors like Allan Megill, Carlo Ginzburg and Anthony Grafton, I regard the interconnections between historical writing and historical research of constitutive importance for history as a cognitive, disciplinary enterprise - also limiting the "fictionality" of history writing fundamentally. ${ }^{21}$

This in no way implies a negative judgment on fictional and metaphorical ways of handling the past. To the contrary: elsewhere, I have argued that authors of fiction usually have been much earlier than professional historians when it came to developing new forms and new contents in representing the past. This especially holds for "liminal", "extreme" experiences, so characteristic of the catastrophic twentieth century. Metaphors in historical writing, in my view, however, should be analysed as both cognitive and as practical linguistic instruments. ${ }^{22}$ Remarkably, both Ankersmit and White (as far as I know) have not analysed the practical dimensions of metaphor, although for historians this dimension should be very obvious. Just think of the practical dimensions (and the historical consequences) of representing specific individuals and groups in quasi-biological concepts as "Fremdkörper", or as "pests" like cockroaches. In my view, this "blind spot" of narrativism is another legacy of "objectivism".

Neither does my argument imply that questions of narrativity can be reduced to questions of the logic of singular descriptive statements. To the contrary, in my view narratological approaches to history writing have been very fruitful in opening our eyes to the perspectives and the constructive aspects and patterns embedded in historical narratives. Maybe this is the moment to "confess" that a recent volume that I have edited, together with Stefan Berger, is even based on narratological ap- 
proaches of national histories. ${ }^{23}$ Therefore, my criticism of narrativism notwithstanding, it is hard to conceive of my recent work in historiography without it.

In my view - and similar views have been developed by authors such as Aviezer Tucker, Mark Bevir and John Zammito - in philosophy of history too we should start by rejecting the very idea of "fixing" individual statements to reality. Instead, we should start by adopting the distinction, introduced by Imre Lakatos (and already present in the thought of conventionalists like Henri Poincaré, Ludwik Fleck and Thomas Kuhn), between observational theories and explanatory theories. We should stop seeing this distinction as a binary opposition and start conceiving it as a sliding scale - as is also suggested by the history of science. When historians claim to give descriptions, they are actually presenting their observational theories, which are as fallible and "unfixable" as their explanatory theories. As a consequence, descriptions are as open to revision and to change as theories - as is amply demonstrated both by the history of science and history of historiography. So, together with Lakatos, Bevir, Zammito and Tucker, I would argue that the distinction between "descriptions" and "theories" - and the latter also sail under the flags of "interpretations" and "explanations" - is a matter of degree and not of a kind. All "theories" are underdetermined by the evidence - and this also holds both for "explanatory" and "observational" theories. Therefore I have positioned myself in a fundamental pluralist framework within which several "true" descriptions and "true" theories of "reality" may coexist (like the wave and particle theories of light in physics or the theory of action and systems theory in the social sciences). And they may coexist peacefully or not - whatever is the case, pluralism is not the same as relativism. This is the practical meaning of what I have called - following Putnam - "internal realism". ${ }^{4}$

As long as philosophers of history don't acknowledge the conventional character of both descriptions and theories, they keep paying tribute to what one could call the last dogma of empiricism: the epistemological privilege of factual over theoretical statements. In contrast. I am pleading with, among others, Nelson Goodman - for an epistemological "equal treatment" of theories and facts, based on the following insight: "Facts are small theories and true theories are big facts." ${ }^{25}$ For most historians and many philosophers of history, this insight still seems to be "a bridge too far".

Since Quine, Kuhn and Lakatos, philosophers of history have better acknowledged that the basic problem in all disciplines is not the direct "fixity" of theories to the world - or their lack of "fixity" but the "fit" between (at least) two kinds of theories among each other. In my view, this is one of the lasting and fundamental insights produced by the "linguistic turn" and by "representationalism". ${ }^{26}$ For those who (mistakenly, I would say) suppose that "realism" is dependent on the idea of a fixed relationship between language and the world, the "linguistic turn" also means a final goodbye to "realism".

Once we have cast the problem of a direct "fixity" of language to the world into the dustbin of empiricist philosophy - where it belongs - we should also realise that there are no sound reasons to believe that narrative substances and representations are devoid of cognitive content (because of their supposed lack of fixity). I have argued repeatedly that it is fruitful to regard the function and the cognitive content of narrative schemes in history as similar to the function and the cognitive 
content of explanatory theories in the sciences. This, of course, does not mean that I do not recognise also the enormous differences between explanatory theories and narrative schemes. The fact that explanatory theories in physics especially can usually be formalised and are expressed in the form of mathematical equations can hardly be overlooked, to give just the most obvious example of a difference.

So much for the problem of the legacies of objectivism in philosophy of history and my reasons for engaging them in some of my texts. Let me now move to the problematic legacies of relativism in philosophy of history, which will bring me to the second critical line of attack in my articles.

Relativism is basically the philosophical double, or Doppelgänger, of objectivism. In whatever variety - and there are quite a few of them - relativists argue against some, or all, claims of objectivism. Relativists typically deny, or downplay, the epistemic claims of history by arguing that "the past" is just "a construction of the present", that doing history is therefore just another form of "politics" or of "ideology". The favourite targets of relativists therefore are the ideas that history can be "true" and "objective" in any meaningful sense. The same relativist point is made by those who argue that the selection and the development of historical narratives in time is completely independent of epistemological arguments and is only dependent on political or aesthetic preferences, as White famously did in Metahistory. ${ }^{27}$

My critique of relativism in philosophy of history is, in a fundamental sense, the complement of my critique of objectivism. While objectivism approaches historical knowledge only from the epistemic viewpoint of the - distant - observer, relativism approaches historical knowledge only from the political viewpoint of the - involved - actor. In my view, philosophy of history needs to include and analyse both the epistemological and the practical viewpoints, and we should avoid the reduction of our analysis of history to one of them. If we analyse historical knowledge only from the external observer's viewpoint, philosophy of history will inevitably shrink to epistemological and methodological analyses. But if we analyse historical knowledge only from the political actor's point of view - and this is the case when we view history exclusively as a form of practical action and when we regard historical theories as devoid of cognitive content - then philosophy of history will inevitably shrink to political and ethical analyses. In my view, therefore, philosophy of history worthy of the name both needs to analyse the historical and the practical past in their interconnections and intersections.

The most interesting insights can be gained by analysing exactly the intersections of epistemology and politics in history - and in this domain I have drawn some inspiration from both Pierre Bourdieu and Michel Foucault. ${ }^{28}$ I have tried to do this by analysing the politics of historians and their politics of comparison in a couple of historiographical controversies, like the Historikerstreit, the Goldhagen debate, the Holocaust debate, the debate about the second German empire and the debate about the national identity of Canada/Quebec. I have argued that basic political options of historians are usually hidden in their choice of "contrast classes", of the cases they use implicitly or explicitly in comparisons. So, my basic interest can be located on a terrain one could call the politics of method. Whether this is a worthwhile approach to philosophy and to historiography is not for me to decide. ${ }^{29}$ 


\section{The 'politics of history'}

Now let me illustrate my approach to the politics of history. Again, I can clarify my way of approaching the politics of historians by comparing my way to the way pursued by Ankersmit. I am now referring to his recent book Sublime Historical Experience, in which he analyses how the writing of history has been conditioned by the political experience of individual historians - especially by the experience of political catastrophes, like the French revolution. Next to the level of the individual historians, Ankersmit distinguishes another, collective level of experience: the level of whole "cultures", whole "civilisations" and of whole "periods". In a remarkable Hegelian fashion, he identifies these collective subjects, like "Western civilisation" or "Indian civilisation", as the subjects of "sublime" or "historical traumas". He also regards these collective subjects as the carriers of "historical consciousness", which in his view is the unintended consequence of a sublime historical trauma. Just like Hegel, Ankersmit focuses on "great individuals" - in his case "great historians" - when he is analysing "historical consciousness".

He then goes on - with his outspoken preference for paradoxes - to argue that the Holocaust does not represent a "historical trauma", as has been assumed by many for a long time, because there is no "collective subject" characterised by it. The Holocaust is only a "psychological trauma" - that is, for the Jews - but not a "sublime historical trauma" for "Western civilisation". He neither considers the possibility that the Holocaust could be a trauma for the Germans, thus ignoring the fact that Germany has been identified as "the Holocaust nation" for a long time - by Günter Grass among others. Last but not least, Ankersmit ignores those historians and memory specialists - like Dan Diner and Aleida Assmann - who argue that the Holocaust does represent a "Zivilisationsbruch" and a "trauma" for the west as a whole..$^{30}$ The same applies for those social scientists that defend Diner's thesis to the world at large - like Jürgen Habermas, John Torpey, Daniel Levy and Natan Sznaider. ${ }^{31}$ This, of course, in no way means that Ankersmit is "relativising" or "downplaying" the Holocaust.

This is not the place to go into all complexities of Ankersmit's analysis of trauma, but in my own, more "empirical" approach to philosophy of history, I am more interested in the question how concepts of trauma and catastrophe are actually being used in historical and historiographical debates - and whether these concepts can be used to explain specific features of these debates (like "silences" and "displacements"). The reason for my more empirical approach is simple: it is because the Holocaust is generally regarded as the traumatic event of the twentieth century, at least as far as the west is concerned (although it was and is never without competitors, especially Stalin's Gulag archipelago). Actually, most of what I find interesting in the politics of history is located exactly between the level of the individual historian and the collective level of Ankersmit's "cultures" and "civilisations". My interest in this "middle ground" (vis-à-vis Ankersmit's "holistic" Hegelian perspective of whole "cultures" and "civilisations") derives from the fact that whenever I have analysed "collective subjects" at a "lower" empirical level than "civilisations" - like, for instance, nations in national historiographies - I found that they are somehow always fundamentally divided among themselves. Therefore, I find it more fruitful not to regard collective subjects as unitary, but rather as the locations of power struggles, including struggles about the Definitionsmacht, how collective identities are represented and how they are essentially contested. ${ }^{32}$ My historiographical analyses 
of the discourses concerning German, Canadian and other national identities can be read as historical "illustrations" of this systematic point. So much for the "systematic" background and coherence of the articles collected in this volume.

\section{NOTES}

1 Chris Lorenz, Przekraczanie granic: eseje z filozofii historii i teorii historiografii, Poznań: Wydawnictwo Poznańskie, 2009.

2 For a recent conceptual history of "microhistory", see Stefan Berger and Chris Lorenz, "Introduction", in Stefan Berger and Chris Lorenz (eds), Nationalizing the Past: Historians as Nation Builders in Modern Europe, Basingstoke: Palgrave Macmillan, 2010, 5-10.

3 Paul Feyerabend, Against Method, London: New Left Books, 1975, 31.

$4 \quad$ W.B. Gallie, "Essentially contested concepts", Proceedings of the Aristotelian Society 56 (1956): 167-198; David Collier et al., "Essentially contested concepts: Debates and applications", Journal of Political Ideologies 11 (2006): 211-246.

5 In this I am following the "historical turn" in post-Kuhnian philosophy of science. For an overview, see John Zammito, A Nice Derangement of Epistemes: Post-Positivism in the Study of Science from Quine to Latourl, Chicago: University of Chicago Press, 2004; Seymour Mauskopf and Alex Roland, "The historiography of science and technology", in Daniel Woolf and Axel Schneider (eds), The Oxford History of Historical Writing, vol. 5, Oxford: Oxford University Press, 2011, 177-199, and Friedrich Stadler, "History and philosophy of science: Zwischen Deskription und Konstruktion", Berichte zur Wissenschaftgeschichte 35 (2012): 217-238.

6 Raymond Martin, The Past Within Us: An Empirical Approach to Philosophy of History, Princeton: Princeton University Press, 1989.

7 Hayden White, “The practical past”, Historein 10 (2010): 10-19; Jörn Rüsen, Lebendige Geschichte: Grundzüge einer Historik III; Formen und Funktionen des historischen Wissens, Göttingen: Vandenhoeck und Ruprecht, 1987.

8 For references and the more extended version of this argument, see the introduction to Berber Bevernage and Chris Lorenz (eds), Breaking up Time: Negotiating the Borders between Present, Past and Future, Göttingen: Vandenhoeck \& Ruprecht, 2013.

9 This problem is also known as the relationship between "is" and "ought". See William D. Hudson, The Is/Ought Question: A Collection of Papers on the Central Problem in Moral Philosophy, London: Macmillan, 1969; Hilary Putnam, The Collapse of the Fact/Value Distinction and Other Essays, Harvard: Harvard University Press, 2002; John Zammito, "The last dogma of positivism: historicist naturalism and the fact/value dichotomy", Journal of the Philosophy of History 6/3 (2012): 305-338.

10 See the forum on Bordercrossings in a 2013 issue of Ruch Filozoficzny, including Krzysztof Brzechczyn, "Recepcja sporów pomiędzy pozytywizmem a narratywizmem w polskiej historii filozofii: Wprowadzenie", and my "Badania pomiędzy historią a filozofią. Wprowadzenie" and "Odpowiedzi moim krytykom", Ruch Filozoficzny 80/3 (2013).

11 See my "Representations of identity: ethnicity, race, class, gender and religion. An introduction to conceptual history", in Stefan Berger and Chris Lorenz (eds), The Contested Nation: Ethnicity, Religion, Class and Gender in National Histories, Houndmills: Palgrave Macmillan, 2008, 24-60. 
12 See my "Unstuck in time. Or: the sudden presence of the past", in Karin Tilmans, Frank van Vree and Jay Winter (eds), Performing the Past: Memory, History and Identity in Modern Europe, Amsterdam: University Press, 2010, 67-105.

13 See Richard Bernstein, Beyond Objectivism and Relativism: Science, Hermeneutics, and Praxis, Philadelphia: University of Pennsylvania Press, 1983.

14 See Mark Bevir, "Why historical distance is not a problem", History and Theory 50 (2011): 24-37; John H. Zammito, "History/philosophy of Science: some lessons for philosophy of history", History and Theory 50 (2011): 390-413; Aviezer Tucker, Our Knowledge of the Past: A Philosophy of Historiography, Cambridge: Cambridge University Press, 2004; Paul A. Roth, "The pasts", History and Theory 51/3 (2012): 313-339.

15 One could argue that Sublime Historical Experience, Stanford: Stanford University Press, 2005, is the only book that was not "foreseen" by Ankersmit in 1983.

16 In his latest book, Meaning, Truth and Reference in Historical Representation (Ithaca: Cornell University Press, 2012), Ankersmit has at last made explicit that he rejects Quine's holism concerning indeterminacy for natural languages while he accepts it for scientific languages. Nevertheless, as before, he basically posits that natural languages are fundamentally different in this respect without providing convincing arguments: "holism is less plausible for natural languages. Outside science there is little room for it ... because natural languages lack the formal coherence characteristic of the tight web of scientific theories" (89-90). Compare this with Mark Bevir, The Logic of the History of Ideas, Cambridge UP: Cambridge 1999, 36-37, who argues that Quine's "semantic holism" also applies to singular descriptive statements in history: "We cannot specify truth conditions for single sentences because what experiences we would accept as showing a sentence to be true will always depend on our broader, theoretical outlook. Single sentences have no fixed meaning. Their semantic meaning depends on the theoretical context in which we locate them."

17 See, for example, Ankersmit, Meaning, Truth and Reference, 101: "Truth and reference are closely related in true description: if we know what the subject term in a sentence refers to, we can determine its truth. But as we know by now nothing can be taken for granted when we move from true description to representation."

18 In terms of philosophy of science, one could argue that Ankersmit remained a Popperian and did not develop into a Lakatossian.

19 Ankersmit, Meaning, Truth and Reference, 89-90.

20 Therefore it is far from accidental that when Ankersmit in 2012 introduced a notion of "truth" characteristic of representations - "representational (historical) truth" - this concerned a completely different, non-propositional, and Heideggerian notion of "truth" as "a self-revelation of the world to us" (109).

21 John S. Nelson, Allan Megill, Donald McCloskey, "The rhetoric of history", in John S. Nelson, Allan Megill, Donald McCloskey (eds), The Rhetoric of the Human Sciences: Language and Argument in Scholarship and Public Affairs, Madison: University of Wisconsin Press, 1987, 235: "The need is not to abandon epistemological standards. These too are part of the discipline and of its conversation. They mark out a successful attempt to make history, like science, cumulative. Yet at the same time they create an obstacle. History that tries to do without rhetoric loses its contact with the wider conversation of mankind." Anthony Grafton, The Footnote: A Curious History, Harvard: Harvard University Press, 1997, 232; Carlo Ginzburg, History, Rhetoric and Proof, Hannover: University Press of New England, 1999; Thomas Mormann, "Ist der Begriff der Repräsentation obsolet?", Zeitschrift für philosophische Forschung 51 (1997): 349-366. 
22 See Eduardo Fermandois, "Kontexte erzeugen: Zur Frage der Wahrheit von Metaphern”, Deutsche Zeitschrift für Philosophie 51 (2003): 427-442. Fermandois argues that whoever describes humans as "wolves" is simultaneously generating anxieties just as someone who describes poverty as a "crime" is raising the normative question of responsibility for poverty. These are non-propositional aspects and functions of metaphors that are as essential as their propositional ones.

23 Stefan Berger and Chris Lorenz (eds), Nationalizing the Past: Historians as Nation Builders in Modern Europe, Basingstoke: Macmillan, 2010.

24 Nicholas Rescher, Pluralism: Against the Demand for Consensus, Oxford: Oxford University Press, 1995; Nelson Goodman, Ways of Worldmaking, Indianapolis: Hackett, 1978, 139-140: "The vaunted claim of community of opinion among scientists is mocked by fundamental controversies raging in almost every science from psychology to astrophysics. And judgments of the Parthenon and the Book of Kells have hardly been more variable than judgments of the laws of gravitation ... any approach to universal accord on anything significant is exceptional."

25 Goodman, Ways of Worldmaking, 6-7.

26 Historically this change corresponds with Wittgenstein's change from his Tractatus to his Philosophical Investigations.

27 For the discussion about White, see Herman Paul, Hayden White: The Historical Imagination, Cambridge: Polity Press, 2011). According to Paul, White subscribes to a "limited relativism" (95-99). I would argue that this still represents relativism.

28 I have elaborated Bourdieu's theory of "scientific fields" in my "Het 'Academisch Poldermodel' en de 'Westforschung' in Nederland", Tijdschrift voor Geschiedenis 118 (2005): 252-270.

29 For the most recent examples, see my "Unstuck in time", and "Double trouble: a comparison of the politics of national history in Germany and Quebec", in Berger and Lorenz (eds), Nationalizing the Past, 49-70.

30 Dan Diner, Beyond the Conceivable: Studies on Germany, Nazism and the Holocaust, Berkeley: University of California Press, 2000; Aleida Assmann, Der Lange Schatten der Vergangenheit: Erinnerungskultur und Geschichtspolitik, Munich: C.H. Beck, 2006. Since 2000 the European Union has followed a similar line of argument in its Stockholm declaration. The Intergovernmental Conference on the Holocaust in Stockholm in 2000 declared "the prevention of another Holocaust to be the civilizational foundation of a new European memory." See www.holocausttaskforce.org/about-the-itf/stockholm-declaration.html (accessed 15 February 2013).

31 Jürgen Habermas, Eine Art Schadensabwicklung, Frankfurt: Suhrkamp, 1987, 115-180; John Torpey, Making Whole What Has Been Smashed: On Reparations Politics, Harvard: University Press, 2006; Daniel Levy and Nathan Sznaider, "Memory unbound: the Holocaust and the formation of cosmopolitan memory", European Journal of Social Theory 5 (2002): 87-106.

See my “Representations of identity”. 